\title{
ENGLISH FOR ACADEMIC PURPOSES FOR THE CONSTRUCTION OF STUDENTS' SCIENTIFIC IDENTITY
}

\author{
JeĻENA ZAŠČERINSKA ${ }^{1 A}$, NATALIA ANDREEVAA ${ }^{B}$, MIHAILS ZAŠČERINSKISA \& LUDMILA ALsEKSEJEVAa \\ Centre for Education and Innovation Research (Latvia) / Immanuel Kant Baltic Federal University (Russia)
}

\begin{abstract}
Modern Europe is considered within such three strategic priorities (Moedas, 2015) as Open Innovation, Open Science, and Openness to the World. These three strategic priorities put a particular emphasis on the construction of students' scientific identity. The guiding research question is as follows: What is the relationship between students' scientific identity and English for Academic Purposes? Therefore, the aim of the present research is to analyse the scientific literature on the relationship between students' scientific identity and English for Academic Purposes underpinning elaboration of a new research question for further studies. The theoretical framing herein will discuss the construction of scientific identity via academic language. The meaning of such key concepts as scientific identity and role models is studied. Moreover, the study demonstrates how the key concepts are related to the idea of English for Academic Purposes. The study demonstrates a logical chain: scientific identity $\rightarrow$ English for Academic Purposes $\rightarrow$ role models $\rightarrow$ an empirical study within a multicultural environment $\rightarrow$ conclusions. Research methods include theoretical and empirical methods. Theoretical methods comprise analysis of theoretical sources and theoretical modelling. In the empirical study, explorative study was employed. Interpretative research paradigm was used. The empirical study carried out in August 2015 involved 22 engineering students at Tallinn University of Technology, Estonia. The results of the empirical study show that engineering students' self-evaluation is of the low level. The findings of the research allow drawing the conclusion that use of role models in English for Academic Purposes is an opportunity for the construction of students' scientific identity. The novel contribution of the paper is revealed in the newly formulated research question. Directions of further research are proposed.
\end{abstract}

Key words: English for Academic Purposes, scientific identity, role models

\section{Introduction}

Modern Europe is considered within such three strategic priorities (Moedas, 2015) as Open Innovation, Open Science, and Openness to the World as shown in Graph 1.

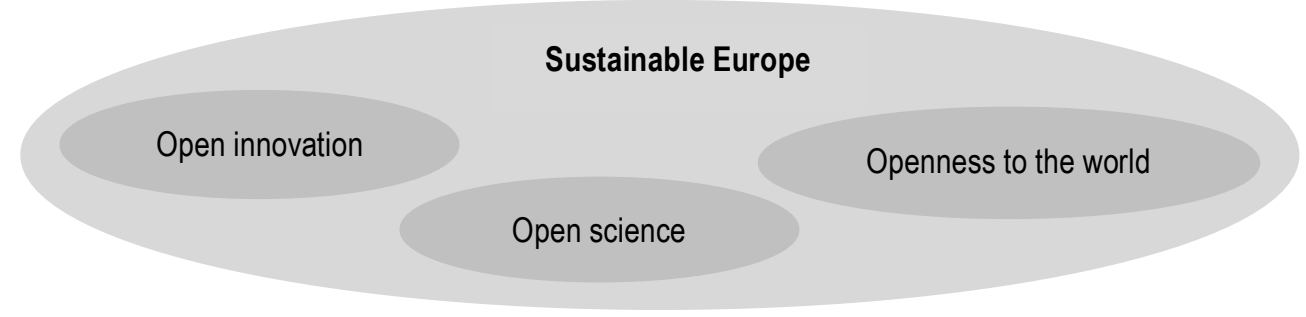

Graph 1. Three strategic priorities for sustainable European future

\footnotetext{
1 E-mail: knezna@inbox.lv
} 
Open innovation is about involving far more actors in the innovation process, from researchers, to entrepreneurs, to users, to governments and civil society (Moedas, 2015). Open innovation means creating the right ecosystems, increasing investment, and bringing more companies and regions into the knowledge economy (Moedas, 2015). Regarding open science, excellent science is the foundation of future prosperity, and that openness is the key to excellence (Moedas, 2015). Open to the World means not only to support collaborative projects but also to enable partnerships between regions and countries (Moedas, 2015).

These three strategic priorities, namely Open Innovation, Open Science, and Openness to the World put a particular emphasis on the construction of students' scientific identity.

The guiding research question is as follows: What is the relationship between students' scientific identity and English for Academic Purposes?

The aim of the present research is to analyse scientific literature on the relationship between students' scientific identity and English for Academic Purposes underpinning elaboration of a new research question for further studies.

Research methods include both theoretical and empirical methods. Theoretical methods comprise the analysis of theoretical sources and theoretical modelling. In the empirical study, an explorative study was employed. The interpretative research paradigm was used. The empirical study carried out in August 2015 involved 22 engineering students at Tallinn University of Technology, Estonia.

The meaning of such key concepts as scientific identity and role models is studied. Moreover, the study demonstrates how the key concepts are related to the idea of English for Academic Purposes. The study demonstrates a logical chain: scientific identity $\rightarrow$ English for Academic Purposes $\rightarrow$ role models $\rightarrow$ an empirical study within a multicultural environment $\rightarrow$ conclusions.

The methodological background of the present research is based on the System-Constructivist Theory (Maslo, 2006, 39). The System-Constructivist Theory is introduced as the New or Social Constructivism Pedagogical Theory. The System-Constructivist Theory is formed by

- Parsons's System Theory (Parsons, 1976) on any activity as a system,

- Luhmann's Theory (Luhmann, 1988) on communication as a system,

- $\quad$ the Theory of Symbolic Interactionalism (Mead, 1973),

- $\quad$ the Theory of Subjectivism (Groeben, 1986).

The System-Constructivist Theory implies the dialectical principle of the unity of opposites that contributes to the understanding of the relationship between external (social, social interaction, teaching, etc) and internal (individual, cognitive activity, learning, etc.) perspectives as the synthesis of external and internal perspectives (Bassus \& Zaščerinska, 2012). By perspective, a certain embodied fundamental assumptions (Barry, 2002, 3) are meant. Application of the System-Constructivist Theory to learning introduced by Reich (Reich, 2005) emphasizes that the human being's point of view depends on the subjective aspect (Maslo, 2007); experience plays the central role in the knowledge construction process (Maslo, 2007). Therein, the subjective aspect of human being's point of view is applicable to the present research.

\section{Theoretical framework}

This theoretical framing will discuss the construction of scientific identity via academic language (Andreeva, Zaščerinska, Glonina, Zaščerinskis \& Aḷeksejeva, 2016).

The use of role models is often said to be a key to successful development of young aspiring specialists (Singh, Vinnicombe \& James, 2003) needed by society and production (Kincāns, 2015). Role models assist in guiding individual's personal development, making important decisions that affect the human well-being and finding satisfaction and fulfillment in individuals' lives. Role models allow constructing a professional identity, too (Singh, Vinnicombe \& James, 2003). Therefore, role models have attracted a lot of research attention. 
The concept of role models (RMs) has been investigated from at least as early as 1970 but definitional ambiguities have plagued the professional literature, particularly in relation to the concept of "mentor" (Ferguson, 2007, 96). Some researchers have used these two terms synonymously and others have made distinctions between them (Ferguson, 2007, 96). For explaining how role modelling functions, the social learning theory (Bandura, 1977) has been used (Singh, Vinnicombe \& James, 2003). The application of the System-Constructivist Theory (Maslo, 2006, 39) has assisted in identifying such elements of role models as individual's identity and cognition as well as social interaction as illustrated in Graph 2 (Zaščerinska, Andreeva, Aleksejeva, 2015).

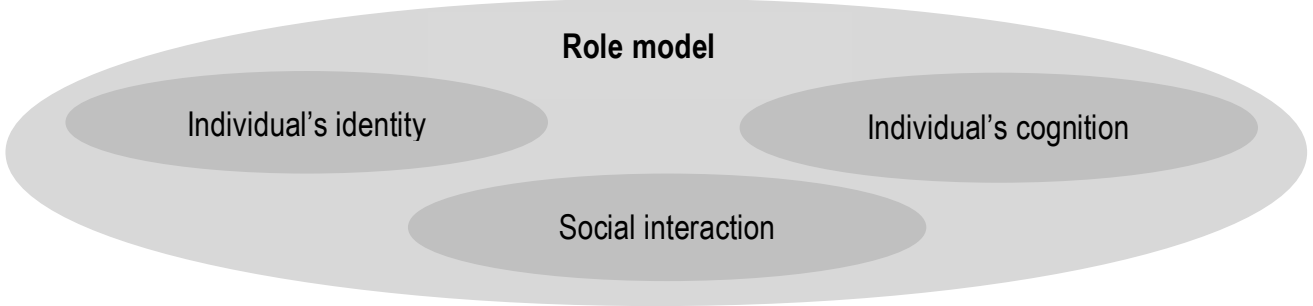

Graph 2. Elements of role models

Gauntlett (2002, p. 214-215) identifies six role model types to demonstrate their distinguishing qualities and possible points of identification for individuals such as:

1. The 'straightforward success' role model: individuals such as sports people, media personalities and politicians who have achieved success within their specific discipline;

2. The 'triumph over difficult circumstances' role model: people who achieve success by prevailing over adversity;

3. The 'challenging stereotypes' role model: figures who challenge traditionally prescribed roles, expectations and assumptions;

4. The 'wholesome' role model: those who are perceived as 'clean living' and therefore deemed an appropriate example for young people to follow;

5. The 'outsider' role model: individuals who reject social conventions and are therefore spurned by mainstream society; and

6. The family role model: this group includes both personal family members and celebrity parents who are admired.

While the importance of role models is generally recognized, their defining characteristics and how they influence education and career choices is still unclear. Analysis of scientific literature reveals that research findings vary: some suggest celebrities are most likely while others have found that family members and friends are still most influential (Bricheno \& Thornton, 2007). In higher education, the impact of role models on medical students has been explored (Wright, Wong \& Newill, 1997). English for Academic Purposes studies as part of higher education are identified as an opportunity for the development of scientific role models (Zaščerinska, Andreeva \& Aleksejeva, 2015). Scientific role model is a part of role model as

- two elements of three of both English for Academic Purposes studies and use of role models coincide as well as

- the construction of individual's identity is mediated via language (Zaščerinskis, Aleksejeva \& Zaščerinska, 2012, 131) in general and scientific identity - via academic language in particular.

However, the use of role models in higher education is traditionally considered from one perspective only: students are users of role models created by their educators. Little attention has been given to such a perspective on use of role models in higher education as students are creators of role models. 
A role model is a person who serves as an example by influencing others (American Academy of Child and Adolescent Psychiatry, 2011). Role models can be also described as a process, namely use of role models.

In higher education, the use of role models are traditionally characterised as one-modal phenomenon. By the use of role models, the tendency of individuals, namely students in the present research, to identify with other people described by the similarity between a role model's and individuals' characteristics, behavior or goals (Gibson, 2004, 136) is meant. Against this background, the authors of the present contribution define the use of role models to be a bi-modal phenomenon as the System-Constructivist Theory that serves as the methodological background of the present research implies the dialectical principle of the unity of opposites (Bassus \& Zaščerinska, 2012). It should be noted that by bi-modal phenomenon, a phenomenon that obtains or exhibits two contrasting modes or forms is meant (Ahrens, Zaščerinska, 2014). Application of the dialectical principle of the unity of opposites (Bassus \& Zaščerinska, 2012) to use of role models emphasizes that use of role models as a bi-modal phenomenon include

- on the one hand, individual's emulation of observed behaviours, styles and attributes of their role models and,

- on the other hand, individual's behaviours, styles and attributes emulated by others.

In other words, the use of role models in general and in higher education in particular is the individual combination of user of role models created by others and creator of role models as demonstrated in Graph 3.

\section{Use of role model}

Individual as user of role models

Individual as creator of role models

\section{Graph 3. Use of role model as a bi-modal phenomenon}

Self-evaluation is a method that allows determining students' levels of role models. Self-evaluation is part of evaluation as depicted in Graph 4 (Ahrens, Bassus, Zaščerinska, 2012).

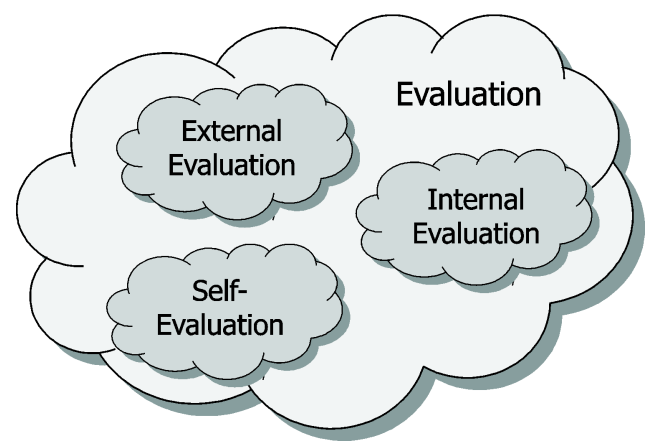

Graph 4. Elements of evaluation

By evaluation, the process of examination and its results are determined (Ahrens, Bassus, Zaščerinska, 2012). Evaluation includes assessment as shown in Graph 5 (Ahrens, Bassus, Zaščerinska, 2012). 


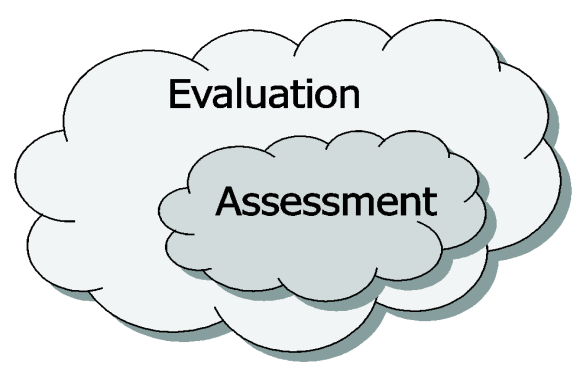

Graph 5. Inter-connections between evaluation and assessment

Traditionally, assessment reveals student advancement, placement and grades (Ahrens, Bassus, Zaščerinska, 2012). In its turn, evaluation provides feedback on the worth or value of a course, module, curriculum or use of role models in the present research. Moreover, evaluations often utilize assessment data along with other resources to make decisions about revising, adopting, or rejecting a course, module, curriculum (Ahrens, Bassus, Zaščerinska, 2012) or use of role models in the present research. Selfevaluation is usually used by the students of a course, module, curriculum (Ahrens, Bassus, Zaščerinska, 2012) or use of role models in the present research.

\section{Empirical study}

The present part of the contribution demonstrates the design, results and findings of the present empirical study.

\subsection{Design of the empirical study}

The design of the present empirical study comprises the purpose and question, sample and methodology of the empirical study. The guiding question of the empirical study was as follows: How do engineering students self-evaluate themselves as role models? The purpose of the empirical study is to analyze engineering students' self-evaluation.

The present empirical study involved 22 respondents within the 11th Baltic Summer School Technical Informatics and Information Technology at Tallinn University of Technology, Tallinn, Estonia, July 20 August 2, 2015. The sample included seven females (F) and 15 males (M). The age of the respondents differed from 20 to 30. All 22 students were involved in Bachelor studies in different fields of electrical engineering such communication, shipping, robotics, etc. Working experience of the students was different, too. The students represented different countries such as Albania, India, Italy, Russia, Malaysia, Estonia, Bhutan, Sri Lanka, Norway, Pakistan, Palestine, Ukraine, United Kingdom, Spain and Germany. Therefore, the sample is multicultural as the respondents with different cultural backgrounds and diverse educational approaches were chosen. Students' different cultural and educational experience emphasized the significance of each engineering student's self-evaluation of the self as a role model (Luka, Ludborza, Maslo, 2009) within the present empirical study. Thus, the group (age, field of study and work, mother tongue, etc.) was heterogeneous.

The interpretive paradigm was used in the empirical study. The interpretive paradigm aims to understand other cultures, from the inside through the use of ethnographic methods such as informal interviewing and participant observation, and establishment of ethically sound relationships (Taylor \& Medina, 2013). The interpretive research paradigm corresponds to the nature of humanistic pedagogy (Lūka, 2008, 52). The interpretive paradigm creates an environment for the development of any individual and helps them to develop their potential (Lūka, 2008, 52). The core of this paradigm is human experience, people's mutual everyday interaction that tends to understand the subjectivity of human experience (Lūka, 2007, 104). The paradigm is aimed at understanding people's activity, how a certain activity is exposed in a certain environment, time, conditions, i.e., how it is exposed in a certain socio-cultural context (Lūka, 2007, 104). Thus, the interpretive paradigm is oriented towards one's conscious activity, and it is future-oriented (Lūka, 2007, p. 104). Interpretive paradigm is characterized by the researcher's practical interest in the research question (Cohen, Manion \& Morrison, 2003). The researcher is the interpreter. 
In order to analyze the engineering students' self-evaluation, the survey was based on the following questionnaire: Question 1: Do you think you are a role model? The evaluation scale of five levels for Question 1 was given, namely, strongly disagree "1", disagree "2", neither disagree nor agree „3", agree "4", and strongly agree "5". The evaluation scale was transformed into the level system as shown in Table 1:

Table 1. Indicators and levels of students' self-evaluation

\begin{tabular}{|l|c|c|c|c|c|}
\hline \multirow{3}{*}{ Indicators } & \multicolumn{5}{|c|}{ Levels } \\
\cline { 2 - 6 } & Level 1 & Level 2 & Level 3 & Level 4 & Level 5 \\
\cline { 2 - 6 } & Very low & Low & Average & Optimal & High \\
\cline { 2 - 7 } & $\mathbf{1}$ & $\mathbf{2}$ & $\mathbf{3}$ & $\mathbf{4}$ & $\mathbf{5}$ \\
\hline Students as role models & $\begin{array}{c}\text { Strongly } \\
\text { disagree }\end{array}$ & Disagree & $\begin{array}{c}\text { Neither disagree } \\
\text { nor agree }\end{array}$ & Agree & $\begin{array}{c}\text { Strongly } \\
\text { agree }\end{array}$ \\
\hline
\end{tabular}

Question 2: For whom (your family members, colleagues, friends, etc) do you think you are a role model? No evaluation scale was applied to Questions 2 as the question was open, and more than one choice was possible.

\subsection{Results of the empirical study}

The results of Question 1 (Students as Role Models) of the questionnaire used in the survey are demonstrated in Graph 6 where:

- the vertical numbers show five levels to measure students' self-evaluation of the self as role models, and

- the horizontal numbers present the code number of the student who participated in the survey.

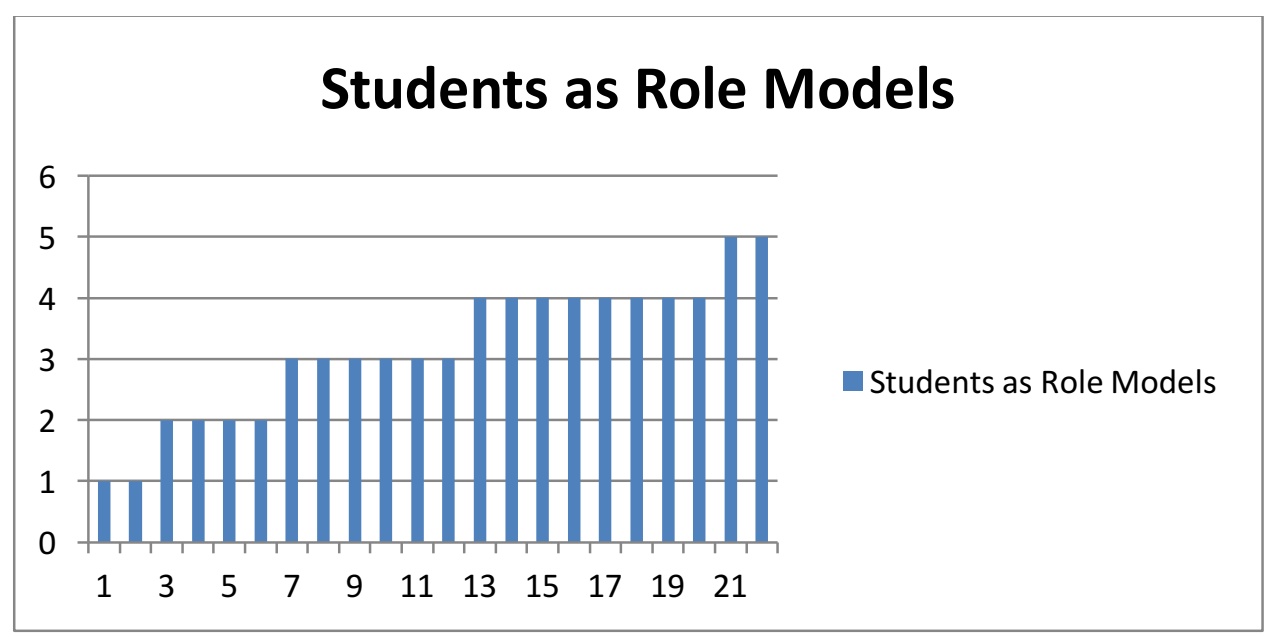

Graph 6. The results of Question 1 (Students as Role Models)

The results of Question 1 (Students as Role Models) show that:

- two students' - two male - self-evaluation refers to the very low level,

- four students' - one male and three female - self-evaluation refers to the low level,

- six students' - four male and two female - self-evaluation refers to the average level,

- eight students' - six male and two female - self-evaluation refers to the optimal level,

- two students' - two male - self-evaluation refers to the high level. 
The data of Question 1 were processed applying Excel software.

Frequencies of the students' answers to Question 1 were determined in order to reveal students' selfevaluation as shown in Table 2:

Table 2. Frequency of the students' answers

\begin{tabular}{|c|c|c|c|c|c|}
\hline Indicator & Level & Gender & $\begin{array}{c}\text { Number of } \\
\text { answers }\end{array}$ & $\begin{array}{c}\text { Total } \\
\text { percentage }\end{array}$ & $\begin{array}{l}\text { Percentage by } \\
\text { gender }\end{array}$ \\
\hline \multirow{10}{*}{$\begin{array}{l}\text { Students as role } \\
\text { models }\end{array}$} & \multirow{2}{*}{ very low } & $M$ & 2 & \multirow{2}{*}{$9.09 \%$} & $9.09 \%$ \\
\hline & & $\mathrm{F}$ & 0 & & $0 \%$ \\
\hline & \multirow{2}{*}{ low } & $M$ & 1 & \multirow{2}{*}{$18.18 \%$} & $4.54 \%$ \\
\hline & & $F$ & 3 & & $13.63 \%$ \\
\hline & \multirow[b]{2}{*}{ average } & $M$ & 4 & \multirow{2}{*}{$27.27 \%$} & $18.18 \%$ \\
\hline & & $\mathrm{F}$ & 2 & & $9.09 \%$ \\
\hline & \multirow[b]{2}{*}{ optimal } & $\mathrm{M}$ & 6 & \multirow{2}{*}{$36.36 \%$} & $27.27 \%$ \\
\hline & & $F$ & 2 & & $9.09 \%$ \\
\hline & \multirow{2}{*}{ high } & $\mathrm{M}$ & 2 & \multirow{2}{*}{$9.09 \%$} & $9.09 \%$ \\
\hline & & $F$ & 0 & & $0 \%$ \\
\hline
\end{tabular}

The survey results demonstrated in Table 2 showed that the engineering students' self-evaluation is of the optimal level $(36.36 \%)$, particularly, male students $(27.27 \%)$. Further on, the mean results indicated in Table 3 determine the low level of the students' self-evaluation of the self as role models (2.95). The findings of the empirical study allow concluding that the male students demonstrated a higher level of the selfevaluation of the self as role models (3.06) in comparison to the female students' self-evaluation of the self as role models (2.85).

Table 3. Mean results

\begin{tabular}{|c|c|c|c|c|c|}
\hline Indicator & Level & Gender & $\begin{array}{c}\text { Number of } \\
\text { answers }\end{array}$ & Mean & Mean by gender \\
\hline \multirow{10}{*}{$\begin{array}{l}\text { Students as role } \\
\text { models }\end{array}$} & \multirow{2}{*}{ very low } & $M$ & 2 & \multirow{10}{*}{2.95} & \multirow{3}{*}{ Male } \\
\hline & & $\mathrm{F}$ & 0 & & \\
\hline & \multirow{2}{*}{ low } & $M$ & 1 & & \\
\hline & & $\mathrm{F}$ & 3 & & \multirow[t]{2}{*}{3.06} \\
\hline & \multirow{2}{*}{ average } & $\mathrm{M}$ & 4 & & \\
\hline & & $\mathrm{F}$ & 2 & & \multirow{5}{*}{ Female } \\
\hline & \multirow{2}{*}{ optimal } & $M$ & 6 & & \\
\hline & & $\mathrm{F}$ & 2 & & \\
\hline & \multirow{2}{*}{ high } & $M$ & 2 & & \\
\hline & & $\mathrm{F}$ & 0 & & \\
\hline
\end{tabular}

The results of Question 2 (For whom Students are Role Models) of the questionnaire used in the survey show that:

- 11 students' - six male and five female - role models influence their family members,

- three students' - two male and one female - role models influence their colleagues,

- 14 students' - 10 male and four female - role models influence their friends,

- one student's - one male - role model influences children as the student works with children.

The survey results of Question 2 indicate that the engineering students are role models for their friends (14 answers), family members (11 answers) and colleagues (three answers). 


\subsection{Findings of the empirical study}

The summarizing content analysis (Mayring, 2004) of the data reveals that the students' self-evaluation is of the low level. The engineering students are role models for

- their friends,

- family members and

- colleagues.

\section{Conclusions}

The theoretical findings of the research allow drawing the conclusion that use of role models is of bimodal nature. The findings of the theoretical research allow drawing the conclusion that use of role models in English for Academic Purposes is an opportunity for the construction of students' scientific identity.

The empirical results demonstrated the low level of the engineering students' self-evaluation. Moreover, the engineering students indicated that they are role models for their friends, family members and colleagues. Therein, there is a need for the increase of the level of the engineering students as role models. And a particular focus has to be put on the increase of the level of the engineering female students as role models as their self-evaluation referred to the low level.

The following research question has been formulated: How to organize use of role models of bi-modular nature in higher education?

The present research has limitations. The inter-connections between role models, bi-modal phenomenon, the use of role models and students' self-evaluation have been set. Another limitation is the empirical study conducted by involving only the engineering students of one higher education institution. Nevertheless, the results of the research - the elaborated questions for a survey - may be used as a basis of analysis of students as role models in other institutions. If the results of other empirical studies had been available for analysis, different results could have been attained. There is a possibility to continue the study.

Further research tends to implement empirical studies in other institutions. The search for relevant methods for evaluation of students as role models is proposed. A comparative research of universities' different programmes and levels could be implemented. A comparative research of different countries could be carried out, too.

\section{References}

Ahrens, A., Bassus, O. \& Zaščerinska, J. (2012). A Methodology of Evaluation of Efficiency of Engineering Curriculum in the Context of Sustainable Development. Management of Sustainable Development (MSD) Journal, Volume 4 (2), 21-28.

Ahrens, A. \& Zaščerinska, J. (2014). Students' Attitude to Interdisciplinary Research. Proceedings of the International Scientifical Conference Society, Integration, Education. Volume I: Higher Education Institutions Pedagogy, School Pedagogy, Pre-School Pedagogy. May, 23th-24th, 2014, pp. 13-23. Rēzekne: Rēzeknes Augstskolas Izdevniecība, 2014. - p. 616.

American Academy of Child and Adolescent Psychiatry (2011). Children and Role Models Facts for Families No. 99; September 2011.

Andreeva, N., Zaščerinska, J., Glonina, O., Zaščerinskis, M. \& Aleksejeva, L. (2016). Bi-Modal Nature of Use of Role Models in Higher Education. Riga Teacher Training and Educational Management Academy 9th International Scientific Conference Theory for Practice in the Education of Contemporary Society. April 14 - 15, 2016, Riga, Latvia. (submitted).

Barry, A.K. (2002). Linguistic Perspectives on Language and Education. USA: Greenwood Publishing Group Inc.

Bassus, O. \& Zaščerinska, J. (2012). Innovation and Higher Education. Berlin: Mensch \& Buch. 
Bricheno, P. \& Thornton, M. (2007) Role model, hero or champion? Children's views concerning role models in Educational Research, 49(4), 383 - 396.

Cohen, L., Manion, L. \& Morrsion, K. (2003). Research Methods in Education. London and New York: Routledge/Falmer Taylor \& Francis Group.

Ferguson, G.M. (2007). Gender differences in role models and academic functioning among Jamaican high school students. Gender in education [Special Issue]. Caribbean Journal of Education, 29(1), 92-125.

Gauntlett, D. (2002) Media, Gender and Identity: An Introduction, London: Routledge.

Gibson, D.E. (2004). Role models in career development: New directions for theory and research. Journal of Vocational Behavior, 65, 134-156.

Groeben, N. (1986). Handeln, Tun, Verhalten als Einheiten einer verstehend-erklärenden Psychologie. Tübingen: Francke.

Kincāns, V. (2015). Ethical Competence and Possibilities of Dialogic Education. Proceedings of the International Scientifical Conference Society, Integration, Education, Volume 1 Higher Education Pedagogy, May, 22nd-23rd, 2015, pp. 206-214. - Rēzekne: Rēzeknes Augstskolas Izdevniecība, 2015. p 468.

Luhmann, N. (1988). Erkenntnis als Konstruktion. Bern: Benteli.

Luka, I. (2007). Development of Students' English for Specific Purposes Competence in Tourism Studies at Tertiary Level. (Unpublished Doctoral Dissertation). Riga: Latvijas Universitāte.

Luka, I. (2008). Students and the educator's co-operation as a means of development of students' ESP competence. Paper presented at the European Conference on Educational Research, University of Göteborg, 10-12.09.2008.

Luka, I., Ludborza, S. \& Maslo, I. (2009). Effectiveness of the use of more than two languages and quality assurance in European interuniversity master studies. Paper presented at the European Conference on Educational Research, University of Vienna, September 28-30, 2009.

Maslo, E. (2007). Transformative Learning Space for Life-Long Foreign Languages Learning. In International Nordic-Baltic Region Conference of FIPLV Innovations in Language Teaching and Learning in the Multicultural Context, 38-46, Rĩga: SIA "Izglitīibas solil".

Maslo, I. (2006). Skolotāju sociālintegrējošās darbības modelēšana. In: I. Maslo (Ed) No zināšanām uz kompetentu darbību, 35.-44. Ipp. Latvijas Universitātes Akadēmiskais apgāds.

Mayring, P. (2004). Qualitative Content Analysis. In U. Flick, E. Von Kardoff and I. Steinke (Eds.). A Companion to Qualitative Research, pp. 266-269. Glasgow: SAGE.

Mead, G.H. (1973). Geist, Identitat, und Gesselschaft. Frankfurt. A.M.

Moedas, C. (2015). Open Innovation, Open Science, Open to the World. European Commission - Speech 'A new start for Europe: Opening up to an ERA of Innovation' Conference, Brussels, Belgium. 22 ${ }^{\text {nd }}$ June 2015.

Parsons, T. (1976). Theorie sozialer Systeme. Opladen: Westdeutscher Verlag.

Reich, K. (2005). Systemisch-konstruktivistische Pädagogik. Weinheim u.a., Beltz.

Singh, V., Vinnicombe, S. \& James, K. (2003). Constructing a Professional Identity: How Young Female Managers Use Role Models. The paper presented at the 2nd Gender, Work \& Organisation Conference, Keele, UK.

Taylor, P.C. \& Medina, M.N.D. (2013). Educational Research Paradigms: From Positivism to Multiparadigmatic. The Journal of Meaning-Centered Education. 1 (Article 2).

Wright, S., Wong, A. \& Newill C. (1997). The Impact of Role Models on Medical Students. J Gen Intern Med. 12(1), 53-6. 
Zaščerinska, J., Andreeva, N. \& Aleksejeva, L. (2015). Use of Role Models within English for Academic Studies. The proceedings of Riga Teacher Training and Educational Management Academy's 10th International Young Scientist Conference, pp. 129-137. Riga: Riga Teacher Training and Educational Management Academy, $137 \mathrm{p}$.

Zaščerinskis, M., Aleksejeva, L. \& Zaščerinska, J. (2012). Plurilinguism in Teachers' Professionalisation: Views of Newly Qualified Pedagogues of Social Work. In: Evija Zača (Ed.), Issue of publications from 1st International conference for students of Social Sciences Nantional Identity: Time, Place, People at the Faculty of Social Sciences, University of Latvia Riga, Latvia, March 15-17, 2012, pp. 131-140. Riga: University of Latvia.

Received: 03/04/2016

Accepted: 22/05/2016 